\title{
The Occupational Health Nursing Education Components Most Influenced by Informatics Technology Based on Gamification and Fogg's Models: a Case Study in Indonesia
}

\author{
Isak Jurun Hans Tukayo1, Mohammad Saljan', I Ketut Swastika1, Syaifoel Hardy² \\ ${ }^{1}$ Department of Nursing Poltekkes Jayapura, Papua, Indonesia \\ ${ }^{2}$ Indonesian Nursing Trainers, Malang, Indonesia
}

Corresponding author: Isak Jurun Hans Tukayo (e-mail: tukayoisak123@gmail.com).

We acknowledge the Ministry of Health of the Republic of Indonesia, Director of Poltekkes Kemenkes Jayapura, Papua, and the teaching staff for supporting the study and all our gratitude to other parties who were willing to participate in our study.

\begin{abstract}
The rapid development of informatics technology (IT) in healthcare in the digital era has not been in line with the development of industrial nursing informatics education in Indonesia. The discrepancy is disturbing the operational activities of nursing clinicians who stand between the need of client, business, and the quality of services. The objective is to explore the benefit to the largest components of education that have changed due to IT interventions. This research used the Case Study method. The instrument was a case management version of the American Board of Occupational Health Nursing (ABOHN). The purposive sampling population was 350 nurses and nursing students who filled a questionnaire based on the Likert Scale, focused on the influence of IT on OHN education. The supporting data was from 15 major campuses in Indonesia that have nursing majors and IT departments, also from ABOHN and other OHN international bodies. The data was processed by the Statistical Package for Social Sciences (SPSS) 25 version, in the table of Pearson Correlation. Gamification and Fogg's Behavior models were used to identify the influence of IT on OHN education. The data analysis showed a significant impact of IT on OHN education with a value of 0.782 . The Influence of IT towards $\mathrm{OH} N$ learning materials based on $\mathrm{G}$ amification and Fogg's M odels also showed of 9 OHN competency categories $(\mathbf{1 0 0 \%})$, indicating the need for IT support was absolute. Case management result projected that the application of Gamification with Fogg's model with the application of IT on the OHN education proved the magnitude influence of IT on 8 components, i.e.: teaching methods, learning materials, learning methods, students' learning interests, campus facilities, lecturer's competencies, campus management, and the education curriculum. The IT intervention will simplify the OHN education system, provide more effective, and efficient $\mathrm{OH}$ nursing practice in the workplace.
\end{abstract}

INDEX TERMS: Informatics, nursing education, teaching, OHN.

\section{INTRODUCTION}

The dependency of modern health education on informatics technology (IT) in this digital era cannot be impeded [1]. The development has an impact on the nursing sector, which has experienced technological changes over the last decade [2], as the world is moving from a hyper-connected to one of digitalized societies [3]. Nursing education continues to develop following technological advances [4]. The development of nursing is so rapid that various studies on future nursing have emerged [5], [6]. The rapid development is such that it is feared that robotic nursing will also emerge [7].
The influence of IT in the nursing practice is so great that without the intervention of technology, it will be difficult to overcome increasingly complex health problems [8]. Similar problem is taking place in the area of occupational health nursing (OHN) as one of nursing branches of knowledge, where the implementation of its education cannot be separated from the dependency on technology [9]. OHN teaching subjects are mostly integrated in community nursing [10]. This is the gap that occurs between previous studies and those of concern in our study. Previous researches focused on IT in nursing [11], [12]. They did not specifically address the impact of technology on OHN teaching. Taking into account the development of 
nursing service technology needs in the industry, it is very important to introduce IT nursing to nursing students for the health needs of workers [13]. According to the International Labor Organization (ILO), the number of workers in the world reaches 3.3 billion people who need occupational health services [14]. Workers in the industrial sector need healthcare services offered by occupational health nursing $(\mathrm{OHN})$. The healthcare services in the industry demand the accuracy of healthcare technology supported by updated IT in line with the technological development and needs of the industrial community [16]. Studies have revealed a lot about the contribution of IT to the development and improvement of health services in the industry [7]. However, 25 campuses hold $\mathrm{OH}$ programs spread across Java, Sumatra, Kalimantan, Bali and Sulawesi offer bright future of $\mathrm{OH}$ nurses' career. The seven nursing specialization programs available at present are maternity nursing, pediatric, mental health, medical-surgical nursing, emergency nursing, community health nursing, and management of nursing [15] In the era of industry 4.0, the industrial world demands the presence of advanced practice of occupational health nurses who are produced through an organized educational process as stated in the 2014 nursing law [18]. Researchers stated that there was a discourse to establish $\mathrm{OHN}$ postgraduate program considering the urgent needs of the field [17] [18]. To meet healthcare service needs in the industries, the Government of Indonesia has organized Occupational health and safety (OHS) training for healthcare workers at the basic level [19]. At the higher education level, $\mathrm{OH}$ education is available at various campuses across the archipelago [20]. In the future, the carrying out OHN education program is inevitable [20]. The World Health Organization (WHO) identified the major duties and roles of nurses in the industrial world, including as clinicians, educators, and researchers [21]. It is not known exactly how much influence IT has on OHN roles and its education. Therefore, it is indispensable to conduct this research to help identify which OHN components are greatly influenced by IT. This research is about the OHN education components most influenced by informatics technology based on Gamification And Fogg's Models. The method used was a case study. Similar methods have been found useful in research related to IT in nursing education [22], [23]. The objective is to provide identified learning subjects influenced by IT on the implementation of the $\mathrm{OHN}$ education program.

\section{METHODS \\ A. DATA COLLECTION}

This research used the Case Study method by applying the Case Management model according to the American Board of Occupational Health Nursing (ABOHN). The first step was assessment by distributing questionnaires. The sample was 350 people, nurses and nursing students, as purposing sampling. It was conducted online on 19 June 2021. The questionnaire was compiled according to the Likert Scale focusing on the influence of informatics technology on OHN education. The content of the questionnaire was developed based on a standardized and validated questionnaire [24], consisting of 3 groups of questions. The first group is about demographic data, the second is about the ability to organize OHN education programs, and the third group is about learning methods using informatics technology. Participants who took part in the study were assumed to agree to the online consent. This study was started after obtaining approval from the research ethics committee of Poltekkes Kemenkes Jayapura of Papua, No.008/KEPK-J/V/2021. Other supporting data were obtained from the 15 major universities that offer nursing and IT majors.

\section{B. DATA MEASUREMENT}

The search for learning models that require IT intervention, namely Gamification and Fogg's Behavior Models were included during the assessment process. The second step was Planning. We planned to match between the tabulated figures of the questionnaire and the data from 15 major universities in Indonesia (13 public, 2 private universities) that offer IT and nursing majors. The data were processed by using the Statistical Package for Social Sciences (SPSS) 25 Version, while the campus informatics data was processed by using the numbering model.

\section{DATA ANALYSIS}

The third step was implementation, namely identifying IT needs in OHN education. The implementation step was carried out by reviewing the content of the core subjects material of the ABOHN version for the OHN course. Each of which was combined with the application of Gamification and Fogg's Behavior Model. The determination of the OHN core learning material is based on the competence of the $\mathrm{OHN}$ recommended by the ABOHN. In the Gamification model, the principles emphasizes on game design and game aesthetics where the work process and work result are the final goals [25]. While in Fogg's Behavior Model the emphasis is on motivation and ability [26]. The goal is to measure whether through IT intervention and the implementation of Gamification and Fogg's Behavior Models, the learning objectives can be achieved. The final stage of this research method was the evaluation results of case management. It was projected in a table of OHN learning materials requirements on IT based on Gamification and Fogg's Models, and the influence of informatics technology on 8 aspects of OHN education.

\section{RESULTS}

\section{A. ASSESSMENT}

In the demographic data showed 335 nurses and 15 nursing students participated during the study, 187 males, 163 females. The majority have a bachelor's degree in nursing (169 people or $48.3 \%$ ) followed by a nursing diploma (137 people or $39.1 \%$ ). Majority of them wanted to continue their education in the OHN specialization (267 people or $76.3 \%$ ). Those who felt confident took part in computer-based programs or Blended Learning (227 people or $64.9 \%$ ). As many as 155 people (44.35) felt less confident with their computer skills, while 195 people $(55.65 \%)$ felt they had technology competencies. Most respondents (204 people or 58.3\%) agreed that OHN education used computers and the internet a lot, where 229 people (65.4) have participated in IT-based learning. The majority (220 people or $62.9 \%$ ) agreed that the right IT assistance would help learning achievement, because 228 people $(65.1 \%)$ were used to using it. A total of 223 people $(63.7 \%)$ liked IT-based learning. 
TABLE 1

15 Major Universities In Indonesia Offer Nursing And IT Majors.

\begin{tabular}{|c|c|c|c|c|c|}
\hline \multirow{2}{*}{ No } & \multirow{2}{*}{\multicolumn{2}{|c|}{ University }} & & \multicolumn{2}{|c|}{ Department } \\
\hline & & & & IT & Nursing \\
\hline 1 & \multicolumn{3}{|l|}{ Indonesia } & $v$ & $v$ \\
\hline 2 & \multicolumn{3}{|l|}{ Padjajaran } & $v$ & $v$ \\
\hline 3 & \multicolumn{3}{|l|}{ Gajah Mada } & $v$ & $v$ \\
\hline 4 & \multicolumn{3}{|l|}{ Riau } & $v$ & $v$ \\
\hline 5 & \multicolumn{3}{|c|}{ Airlangga } & $v$ & $v$ \\
\hline 6 & \multicolumn{3}{|c|}{ Muhammadiyah Yogyakarta } & $v$ & $v$ \\
\hline 7 & \multicolumn{3}{|c|}{ Muhammadiyah Jakarta } & $v$ & $v$ \\
\hline 8 & \multicolumn{3}{|c|}{ Diponegoro } & $v$ & $v$ \\
\hline 9 & \multicolumn{3}{|l|}{ Brawijaya } & $v$ & $v$ \\
\hline 10 & \multicolumn{3}{|l|}{ Andalas } & $v$ & $v$ \\
\hline 11 & \multicolumn{3}{|c|}{ Sumetera Utara } & $v$ & $v$ \\
\hline 12 & \multicolumn{3}{|c|}{ Jember } & $v$ & $v$ \\
\hline 13 & \multicolumn{3}{|c|}{ Jenderal Soedirman } & $v$ & $v$ \\
\hline 14 & \multicolumn{3}{|c|}{ Syiah Kuala } & $v$ & $v$ \\
\hline 15 & \multicolumn{3}{|c|}{ Syarif Hidayatullah } & $v$ & $v$ \\
\hline \multicolumn{6}{|c|}{$\begin{array}{c}\text { TABEL } 2 \\
\text { Pearson Correlations } \\
\end{array}$} \\
\hline \multicolumn{3}{|c|}{ Component } & OHN Education & & $\begin{array}{l}\text { natics } \\
\text { ology }\end{array}$ \\
\hline \multirow{3}{*}{\multicolumn{2}{|c|}{ Informatics Technology }} & Pearson Correlation & 1 & & $2^{* *}$ \\
\hline & & Sig. (2-tailed) & & & 00 \\
\hline & & $\mathrm{N}$ & 350 & & 50 \\
\hline \multirow{3}{*}{\multicolumn{2}{|c|}{ OHN Education }} & Pearson Correlation & $.782^{* *}$ & & 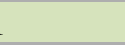 \\
\hline & & Sig. (2-tailed) & .000 & & \\
\hline & & $\mathrm{N}$ & 350 & & 50 \\
\hline
\end{tabular}

The study results are supported by data from 15 major universities, both public and private universities in 12 provinces in Indonesia (TABLE 1) which have majors in nursing and IT. Currently, 25 campuses offer Occupational Health majors (Mutu institute, 2021). The TABLE 1 illustrates that the IT and nursing majors are very common majors and are widely available on many campuses in various regions in Indonesia.

\section{B. PLANNING}

After the assessment, the next step was the search for learning models that require IT intervention, specifically Gamification and Fogg's Behavior Models. Gamification is well known as the foundation of using IT in the learning process [27]. Many studies recommend the model as a background for IT intervention in education [28]. While Fogg's Behavior Model we chose because the theory is widely used by researchers in the field of education that require IT support [26]. Below table is the result of data processing from the questionnaires in the Pearson Correlation TABLE 2.

Based on the above table, the Informatics Technology variable with OHN Education (Y) has a sign value of 0.000 , which means $<(0.000<0.05)$. The Pearson Correlation value of the $\mathrm{X}$ and $\mathrm{Y}$ variables has a strong and unidirectional relationship with a value of 0.782 . In conclusion, there is a significant correlation and influence between Informatics Technology and OHN Education (Y).

\section{IMPLEMENTATION}

In the implementation stage, we identified the OHN education need of IT by combining OHN learning subjects based on categories of competencies. It is accompanied by a brief description then combined with the application of Gamification and Fogg's Behavior Model. Gamification requires its use with the availability of Game Design and Game Aesthetics/Impact. Meanwhile, Fogg's Behavior Model requires motivation and ability. If both conditions are met, both learning models can be carried out The TABLE 3 above consists of 9 $\mathrm{OHN}$ competencies recommended by $\mathrm{ABOHN}$ in $\mathrm{OHN}$ education. After joining with Gamification and Fogg's Behavior models, the results showed that nine OHN competencies merged in learning materials matched the requirements of the two models. This proves that to run OHN learning materials into practice, IT intervention in inevitable. In other words, the OHN education process will occur with the help of IT.

\section{EVALUATION}


TABLE 3.

The OHN learning materials requirement on IT based on Gamification and Fogg's Models

\begin{tabular}{|c|c|c|c|c|c|c|}
\hline \multirow[b]{2}{*}{ No } & \multirow{2}{*}{$\begin{array}{c}\text { OHN Learning Subjects } \\
\text { based on Categories of } \\
\text { Competencies }\end{array}$} & \multirow[b]{2}{*}{ Brief Description } & \multicolumn{2}{|c|}{$\begin{array}{l}\text { Gamification } \\
\text { Requirement }\end{array}$} & \multicolumn{2}{|c|}{$\begin{array}{l}\text { Fogg's Model } \\
\text { Requirement }\end{array}$} \\
\hline & & & $\begin{array}{l}\text { Game } \\
\text { Design }\end{array}$ & $\begin{array}{l}\text { Game } \\
\text { Esthetic/ } \\
\text { Impact }\end{array}$ & $\begin{array}{l}\text { Moti- } \\
\text { vation }\end{array}$ & $\begin{array}{l}\text { Abili- } \\
\text { ty }\end{array}$ \\
\hline
\end{tabular}

1 Clinical Practice

2 Workforce, Workplace, and the Environment

3 Health and Safety Education and Training

\begin{tabular}{|c|c|}
\hline 4 & Case Management \\
\hline 5 & $\begin{array}{l}\text { Management, Business and } \\
\text { Leadership }\end{array}$ \\
\hline
\end{tabular}

6 Research

8 Health Promotion and

8 Disease Prevention

9 Professionalism

Document the nursing process in care management by assessing, diagnosing and treating with appropriate standards and laws.

Coordinate health screening and survey-llance programs and monitor the work

Environment to protect the health and safety of workers.

Implement occupation-nal and environmental health and safety education and training.

Identify the need for case management intervention and be able to conduct a

thorough and objective assessment of the client's current status and case management needs.

Responsible for cost-effective occupational

health services and programs and continu-ous monitoring for cost effective products and services.

Identify and share resources and applications that help support relevant evidence-based practices.

Bring awareness of current legislative activities that may impact nursing practices, workers workplaces and the environment.

$\begin{array}{llll}v & v & v & v\end{array}$

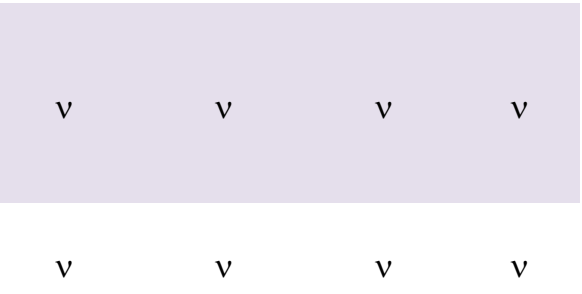

Assess the health needs of workers and worker populations. Maintain scientific, regulatory and business knowledge appropriate to the nursing profession.

The evaluation is the final stage of this case study which provides the results of the entire case management process. The result was presented on a table containing what components of education, which aspect can be influenced by IT, in what forms of intervention, and how we can find them. The evaluation template was prepared based on $\mathrm{OHN}$ educational standards and competencies in various international institutions supported by health and nursing laws, legislation, findings of experts published in international journals, as well as OHN education policies on various campuses. All sources could be accessed by the help of IT. The sources are supported by well-established and standardized IT facilities. In other words, IT has a great influence on various aspects of $\mathrm{OHN}$ education, in terms of students, lecturers, campus management, curriculum, and even the education laws, which IT can change due to the demands to adapt the IT developments in the modern world.

The TABLE 4 above shows an illustration that in every aspect of learning activities in the operation of OHN education, all of them involve IT intervention. The table demonstrates of the 8 components of implementing OHN education, none of them stands alone without the involvement of IT. 
TABLE 4.

Influence of Informatics Technology towards OHN Education

\begin{tabular}{|c|c|c|c|}
\hline No. & $\begin{array}{l}\text { Component that can be } \\
\text { Influenced }\end{array}$ & Informatics intervention to education & How to find out \\
\hline 1 & Learning methods & $\begin{array}{l}\text { From offline to online education. From } \\
\text { direct to indirect learning. }\end{array}$ & $\begin{array}{l}\text { From curriculum objectives, } \\
\text { international journals on OHN. }\end{array}$ \\
\hline 2 & Subject materials & $\begin{array}{l}\text { The use of laboratory practice, nursing } \\
\text { and medical equipment, computer, } \\
\text { laptop }\end{array}$ & $\begin{array}{l}\text { From curriculum of OHN, global } \\
\text { trend, international standard, OHN } \\
\text { organization, international journals. }\end{array}$ \\
\hline 3 & $\begin{array}{l}\text { Competencies } \\
\text { students' learning }\end{array}$ & $\begin{array}{l}\text { To become independent learning, } \\
\text { group assignment, communica-tion } \\
\text { and presentation skills online, } \\
\text { computer skills, international standard } \\
\text { competency of OHN. }\end{array}$ & $\begin{array}{l}\text { From the questionnaire, research on } \\
\text { students studying OHN. }\end{array}$ \\
\hline 4 & Learning interests & $\begin{array}{l}\text { Students will have to change the } \\
\text { conventional study interest to IT way } \\
\text { of studying. }\end{array}$ & $\begin{array}{l}\text { From the questionnaire and global } \\
\text { research on students' study interest } \\
\text { on IT. }\end{array}$ \\
\hline 5 & Learning facilities & $\begin{array}{l}\text { Lecturers, facilitator and students } \\
\text { should be provided with hand phone, } \\
\text { laptops, desk top computer, access to } \\
\text { international library and internet. }\end{array}$ & $\begin{array}{l}\text { From the informatics on campuses' } \\
\text { websites, OHN organizations and } \\
\text { OHN practitioners and journals. }\end{array}$ \\
\hline 6 & Lecturers' competencies & $\begin{array}{l}\text { The requirements of computer } \\
\text { knowledge, software application, } \\
\text { presentation and well trained in } \\
\text { communication skills, power point } \\
\text { making skills, access to global network } \\
\text { of OHN professionals and other IT- } \\
\text { related skills. }\end{array}$ & $\begin{array}{l}\text { From OHN curriculum, education } \\
\text { and nursing law and regulations. }\end{array}$ \\
\hline 7 & Campus management & $\begin{array}{l}\text { Networking, computers, internet, } \\
\text { online library, and other access of } \\
\text { student-related informatics system. }\end{array}$ & $\begin{array}{l}\text { From internal campus, international } \\
\text { campus offering OHN class, and } \\
\text { international journals. }\end{array}$ \\
\hline 8 & Education curriculum & $\begin{array}{l}\text { The need to adopt modern technology } \\
\text { in the curriculum from offline to } \\
\text { online learning in the education } \\
\text { system. }\end{array}$ & $\begin{array}{l}\text { From state constitution, education } \\
\text { and nursing laws, higher education } \\
\text { regulations, and international } \\
\text { universities offering OHN degrees. }\end{array}$ \\
\hline
\end{tabular}

The weakness of this research is that it was not carried out directly by applying information technology applications that are carried out in the field into the teaching and learning process of OHN. The difference with previous research is Previous research has applied information technology in direct teaching although it has not specifically touched on $\mathrm{OHN}$. Therefore it is not known how much the value of the benefits of this study to the community.

\section{DISCUSSION}

This case study used Case Management of ABOHN as the method. The case management was used because it is made by the largest OHN agency in the USA and as one of the world's OHN references [29]. Case management is widely applied clinically but can be applied in the sense of case management in general, including in the field of education as we reveal in this study [30]. Case management in education applies more or less the same principles, namely assessment, planning, implementation, and evaluation. In this case study, we found four major problems. First, poor IT knowledge for students; second, incorrect teaching-learning methods; third, lack of nursing informatics major; and the fourth is the need for nursing informatics training for $\mathrm{OH}$ nurses. In case management, the identified problems were selected on the basis of urgency and practical implementation after offering the solution [31].

\section{A. POOR IT KNOWLEDGE}

Analysis of the questionnaire showed 155 participants (44.4\%) were less confident with their computer skills. In the future, the inequality will affect the continuity of the teaching and learning process. International campuses that offer OHN programs always demand the ability to operate a computer [32]. ABOHN which organizes certified case management training recommend the proficiency to operate computers for its participants, because the exams are also conducted online [33]. The Introduction to computer course material is common material at the postgraduate level or any specialist programs. The program aims to make students have sufficient provisions related to informatics technology. All OHN courses require computer and internet intervention, so students who do not yet understand how to operate a computer and its intricacies will face problems in learning [22]. Therefore, it is recommended that before participating in the OHN education program, it is compulsory to ensure that individual students know about computers and at least Microsoft Office. At this evaluation stage, researchers did not identify more detail about the ability of students, in which IT department, hardware, software or how 
to operate it. Likewise, from the lecturer's point of view, the details of the IT's influence are not listed either, including from other supporting elements. Therefore, the measurement accuracy of IT's influence to students and lecturers cannot be called perfect without having comprehensive assessment.

\section{B. INCORRECT TEACHING-LEARNING METHODS}

The questionnaire tabulation showed 220 participants $(62.3 \%)$ agreed that learning using IT requires careful planning. Incorrect IT knowledge will greatly affect the teaching and learning process [23]. In the field practice, researchers assumed that the participants in this study have already encountered cases where the teaching and learning process was disrupted because they did not have IT proficiency. Weaknesses in those aspects can come from the internet provider, the quality of the gadget, laptop, or desktop, as well as the ability to operate applications and presentation skills. All of them are very important for the continuity of teaching and learning. The teaching and learning process using IT is very much different from face-to-face teaching. Many studies have shown the relationship between IT mastery and academic achievement [32]. The evidence shows a close relationship between IT mastery and learning methods. For this reason, it is recommended for lecturers in particular to study teaching models that use IT as a tool, for example about student assignments, group discussions, evaluations, to various forms of tests. Students are also required to do the same thing, viz. learning new applications, starting from student submission, research, library search, group discussion, etc.

\section{LACK OF NURSING INFORMATICS EDUCATION}

The case study data only show 15 major campuses are as examples of universities that offer nursing sciences and IT programs. The campuses have IT majors at the undergraduate level, but at the same time they don't offer informatics nursing education. The availability of IT study programs at the same campus is very beneficial for the study of nursing science, as a synergy. In the previous section OHN learning materials that require IT intervention were identified. With the IT study program on the same campus, it will provide a great opportunity to save fund, time, energy and facilities. Unfortunately with those all facilities, Nursing Informatics specialization program has not yet been established in Indonesia. Nursing informatics majors so far only exist in developed countries. The USA has 20 of the best IT campuses with a major in nursing informatics. Even though Indonesia already has 243 of the best IT campuses, the evidence shows that there is no effort to empower the existing potential to contribute to each other from one specialization to another. It is suggested to do more research regarding the synergy of the two majors to attract the establishment of nursing informatics education.

\section{NURSING INFORMATICS TRAINING NEED}

This case study explicitly does not state whether there is a nursing informatics training institution. This issue was raised because OHN competencies are very close to IT competencies in their work practices. OHN nurses in Indonesia are called 'Paramedics' in their workplace [15][17]. So far, training related to $\mathrm{OH}$ is provided by the Government. The period of OHS training lasts for 4-5 days [34]. The training material does not include nursing informatics [35]. Whereas in the healthcare industry, nurses are the most dominating profession in the health industrial services [36]. The teaching of nursing science is suggested to refer to the future [37]. OHN teaching needs to identify the future challenges of information technology, in order to be able to adapt to the times [38].That deficiency deserves attention and a solution. The $\mathrm{OH}$ nurses are very much needed and their IT competencies play a big role in the continuity and quality of their work [39]. Therefore, while waiting for the establishment of the OHN specialist education program, it is recommended to include nursing informatics as one of the essential training materials.

\section{CONCLUSION}

The implementation of OHN education and its teaching and learning process has changed in line with changes in informatics technology. The influence of IT is so great that it requires carefulness in responding to it from an educational perspective. This research is a case study of the IT intervention in $\mathrm{OHN}$ teaching in Indonesia. The objective is to explore the benefit to the largest components of education that have changed due to IT interventions. The study's results proved the magnitude influence of IT on 8 components, i.e.: teaching methods, learning materials, learning methods, students' learning interests, campus facilities, lecturer's competencies, campus management, and the education curriculum. The study recommends that the IT intervention will simplify the OHN education system, provide more effective and efficient $\mathrm{OH}$ nursing practice in the workplace. However, for further research, this study suggests the need for direct application of OHN teaching materials, with an emphasis on both theory and practice using information technology.

\section{REFERENCES}

[1] O. Bodenreider et al, Studies in Health Technology and Informatics, vol. 225. 2016.

[2] C. Saputra and Y. Arif, "Nursing Informatics System in Health Care Delivery," KnE Life Sci., vol. 4, no. 10, p. 38, 2019, doi: 10.18502/kls.v4i10.3827.

[3] ECLAC-UN, “Technologies New Future," Publication, 2021.

[4] K. Jeleč, S. Sukalić, and A. Friganović, "Nursing and implementation of modern technology," Signa Vitae, vol. 12, no. 1, pp. 23-27, 2016, doi: 10.22514/SV121.102016.3.

[5] R. G. Booth, G. Strudwick, S. McBride, S. O'Connor, and A. L. Solano López, "How the nursing profession should adapt for a digital future," $B M J$, vol. 373, pp. 15, 2021, doi: 10.1136/bmj.n1190.

[6] P. A. Grady, "Charting future directions in nursing research: NINR's Innovative questions initiative," $J$. Nurs. Scholarsh., vol. 46, no. 3, pp. 143-143, 2014, doi: 10.1111/jnu.12078.

[7] C. Huston, "The impact of emerging technology on nursing care : Warp speed ahead," no. June 2013, 2016, doi: 10.3912/OJIN.Vol18No02Man01.

[8] I. Orhan and E. K. Serin, "Use of Health Technologies by Nurses and Their Thoughts on Technology.," Int. J. Caring Sci., vol. 12, no. 1, pp. 416-422, 2019.

[9] A. Lee, "The role of informatics in nursing," Nurs. Made Incred. Easy, vol. 12, no. 4, p. 55, 2014, doi: 10.1097/01.NME.0000450294.60987.00.

[10] S. Hardy, "Paradigma Baru Manajemen Occupational 
Health Nursing Dalam Pembelajaran Community of Nursing," J. Keperawatan, vol. 3, no. 2, p. 138435 , 2012.

[11] H. Lee, H. Min, S. M. Oh, and K. Shim, "Mobile technology in undergraduate nursing education: A systematic review," Healthc. Inform. Res., vol. 24 , no. 2 , pp. 97-108, 2018, doi: 10.4258/hir.2018.24.2.97.

[12] M. M. James, "Challenges Faced by Nurses in India-the Major Workforce of the Healthcare System," Nurs. Care Open Access J., vol. 2, no. 4, pp. 112-114, 2017, doi: 10.15406/ncoaj.2017.02.00045.

[13] K. Morin, "Nursing education: The past, present and future," J. Heal. Spec., vol. 2, no. 4, p. 136, 2014, doi: 10.4103/1658-600x.142781.

[14] ILO, "The world of work and COVID-19," United Nations, vol. 06, no. June, p. 27, 2020.

[15] I. J. H. Tukayo and S. Hardy, "The Comparison of Work Productivity Between Nurses with Insight of Occupational Health Nursing (OHN) and of Those Without It," J . Keperawatan, vol. 11, no. 2, pp. 127-134, 2020, doi: 10.22219/jk.v11i2.12107.

[16] S. McBride and M. Tietze, Nursing Informatics for the Advanced Practice Nurse. 2018.

[17] I. Tukayo, H. Jurun, S. Hardy, M. Saljan, and I. K. Swastika, "The Challenges in Poltekkes Kemenkes Jayapura ( A Case Study )," pp. 71-77, 2021, doi: 10.26699/jnk.v8i1.ART.p.

[18] R. I. Kemenkes, “Undang-Undang RI No.38 Tahun 2014 Tentang Keperawatan,” Dep. Kesehat. RI, p. 52, 2014.

[19] S. Putri, S. Santoso, and E. P. Rahayu, "Pelaksanaan Keselamatan Dan Kesehatan Kerja Terhadap Kejadian Kecelakaan Kerja Perawat Rumah Sakit," J. Endur., vol. 3, no. 2, p. 271, 2018, doi: 10.22216/jen.v3i2.2686.

[20] S. Hardy, A. H. Sanudin, and R. Afzal, "Analysis of Imbalance Between Government Regulations and Nursing Education on Industrial Nurses," vol. 3, no. 1, pp. 17-26, 2021.

[21] WHO Regional office for Europe, "The Role of the Occupational Health Nurse in Workplace Health Management.," Occup. Health (Auckl)., no. c, pp. 1-4, 2001, [Online]. Available: https://www.who.int/occupational_health/regions/en/oeh eurnursing.pdf.

[22] B. Ainsley and A. Brown, "The impact of informatics on nursing education: A review of the literature," J . Contin. Educ. Nurs., vol. 40, no. 5, pp. 228-232, 2009, doi: 10.3928/00220124-20090422-02.

[23] M. K. Aathi, "Nursing Informatics: The Emerging Field," Asian J. Nurs. Educ. Res., vol. 4, no. 1, pp. 127130, 2014.

[24] M. I. M. Ibrahim, C. W. Phing, and S. Palaian, "Evaluation of knowledge and perception of Malaysian health professionals about telemedicine," J. Clin. Diagnostic Res., vol. 4, no. 1, pp. 2052-2056, 2010.

[25] R. I. Malas and T. M. Hamtini, "A gamified e-learning design model to promote and improve learning," Int. Rev. Comput. Softw., vol. 11, no. 1, pp. 8-19, 2016, doi: 10.15866/irecos.v11i1.7913.

[26] F. P. De Toledo, S. Devincenzi, V. Kwecko, F. P. Mota, and S. S. D. C. Botelho, "A framework for modeling Persuasive Technologies based on the Fogg Behavior Model," Proc. - Front. Educ. Conf. FIE, vol. 2018-

Octob, no. October, 2019, doi:

10.1109/FIE.2018.8659195.

[27] D. Rutkauskiene, D. Gudoniene, and R. Maskeliunas, "Smart Education and e-Learning 2016," vol. 59, no. December 2017, pp. 291-301, 2016, doi: 10.1007/978-3319-39690-3.

[28] K. Seaborn and D. I. Fels, "Gamification in theory and action: A survey," Int. J. Hum. Comput. Stud., vol. 74, no. December 2019, pp. 14-31, 2015, doi: 10.1016/j.ijhcs.2014.09.006.

[29] ABOHN, Occupational health nursing profession. 2016.

[30] NaBITA, "Case Management in Higher Education," p. 44, 2012.

[31] Department of Elder Affairs, "Intake, Prioritization and Case Management,” no. July, pp. 1-91, 2009.

[32] I. Cimermanová, "The effect of learning styles on academic achievement in different forms of teaching," Int. J. Instr., vol. 11, no. 3, pp. 219-232, 2018, doi: 10.12973/iji.2018.11316a.

[33] E. Ogden, "Candidate Handbook Case Management Examination."

[34] BPPSDM, Kurikulum pelatihan untuk perawat. 2018.

[35] Ratnawati, "Modul HIPERKES," 2018.

[36] D. Lalloo, E. Demou, S. Kiran, M. Gaffney, M. Stevenson, and E. B. Macdonald, "Core competencies for UK occupational health nurses: A Delphi study," Occup. Med. (Chic. III)., vol. 66, no. 8, pp. 649-655, 2016, doi: 10.1093/occmed/kqw089.

[37] A. J. Ramos-Morcillo, C. Leal-Costa, J. E. MoralGarcía, and M. Ruzafa-Martínez, "Experiences of nursing students during the abrupt change from face-toface to e-learning education during the first month of confinement due to COVID-19 in Spain," Int. J. Environ. Res. Public Health, vol. 17, no. 15, pp. 1-15, 2020, doi: 10.3390/ijerph17155519.

[38] M. A. Fawaz, A. M. Hamdan-Mansour, and A. Tassi, "Challenges facing nursing education in the advanced healthcare environment," Int. J. Africa Nurs. Sci., vol. 9, no. February, pp. 105-110, 2018, doi: 10.1016/j.ijans.2018.10.005.

[39] D. Dyck, "Case Management: Where Theory Meets Occupational Health Nursing Practice?," OOHNA J., vol. 38, no. 2, pp. 28-40, 2019, [Online]. Available: http://search.ebscohost.com/login.aspx?direct=true $\& \mathrm{db}=$ ccm\&AN=139157284\&site=ehost-live.

\section{AUTHORS BIOGRAPHIES}

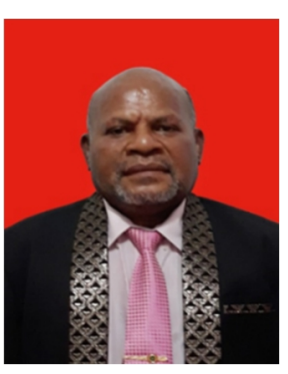

ISAK JURUN HANS TUKAYO (M'1964) Graduated from Diploma of Nursing of UNCEN in 1987, Bachelor of Nursing of the University of Indonesia in 1997, Master of Nursing of UI in 2000 and Faculty of Medicine of UNHAS in 2016. He was appointed as a civil servant for the Papua Health Regional Office since 1988 at Effata Wineuk Hospital, and worked as a coordinator for Community Health Development in the working areas of Desa, wine, Pronggoli, Panggema, Kosarek, Welarek, Mimbaham, Walma, Apalapsili, Pagai and surrounding areas. In 19821984 as a laboratory and X-ray staff at Efatha Wineuk Hospital. In 1997 he was placed at the Integrated Health Academy now Poltekkes Kemenkes Jayapura, as a permanent lecturer. Strategic positions that have been held 
ranging from head of the department, deputy director of academics and deputy director of personnel and finance, as well as serving as director of the Health Polytechnic of the Ministry of Health Jayapura for two periods from 2010 to December 2018. In addition, as founder and concurrently Chair of the Education Program Nurse is now PSIK-FK UNCEN and a member of its senate from 2008 to 2010. Currently as a permanent lecturer with the functional rank of Head Lector at Poltekkes Jayapura. His major interest are in Community Health Nursing. Dr. Isak JH Tukayo, M.Sc.'s books are: 1. Character Based Nursing Education Management (2020); 2. Occupational Health Nursing Management (2020) and 3. Life Skills for the Nursing Profession (2021).

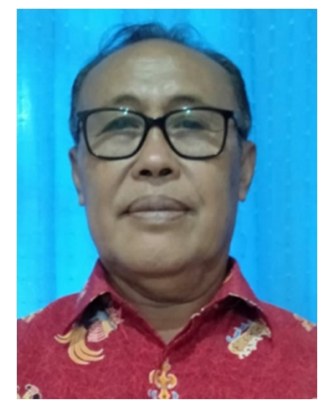

MOHAMMAD SALJAN (M/1965). Education background: Diploma of Nursing of UNCEN (1987), Bachelor of Nursing of UI (1998), Master of Nursing of UI (2005). In 1998 he was assigned to the Merauke District Health Office. In 1988 he was transferred to the Mopa Baru Health Center in Merauke. From 1999 to 2005 he served at SPK Merauke, in 2012 he moved as a lecturer at the Jayapura Poltekkes, from 2013 to 2018 he became the Head of the Merauke Diploma Nursing Program up to now. Mohammad Saljan, M.N is the head of District (2017-2022). Indonesian Nursing Association of Merauke

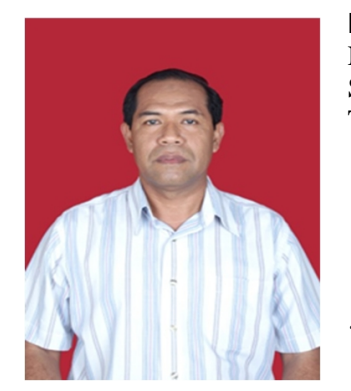

I KETUT SWASTIKA (M/1960). Education: Nursing School of Jayapura, Teacher Nursing School of Surabaya, Nursing Diploma of Teaching of Pajajaran Bandung, Bachelor of
Education of UNCEN, Bachelor of Nursing (UNCEN) and Master of Health (University of Yogyakarta). He worked at Psychological Hospital of Abepura for 5 years. As nursing teacher of Jayapura for 6 years. Since 1994 up to now he has been appointed as lecturer at Polytechnic of Health of Jayapura. I Ketut Swastika, MPH current position is as Head Lector of Poltekkes Jayapura.

SYAIFOEL HARDY (M/1963). Education background: Diploma of Nursing of Malang (1982), Bachelor of Nursing of USQ (2002), Post Graduate of

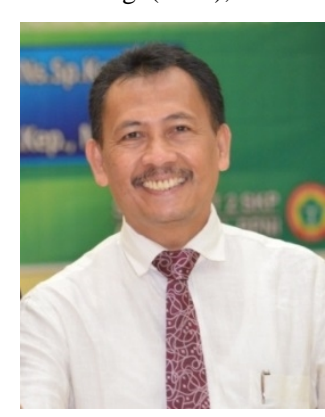
Hospital and Healthcare Management of Pune India (2003), Master of Nursing of USQ (2004). He worked as civil servant at Lawang Nursing School (1983-1987, Panti Waluya Nursing School (1987-1981). He worked in the Middle East from 1993-2014 as staff nurse in Kuwait, Occupational Health Nurse in UAE and as Chief $\mathrm{OHN}$ in Qatar Petroleum. His research interests are in nursing education and occupational health. His published works include Motivating Nursing (2016), Fighting Fate of Nurses (2018), and Management of Occupational Health Nursing (2020). Syaifoel Hardy, M.N received Diaspora Award Winner (2012), Al Hasbah Award (2012), Best Motivator Life Time Achievement Award (2012), Best Motivator (2010) and Best Employee of Dubai Government Workshop (2005). 